\title{
MATHEMATICAL MODELLING AND ESTIMATION OF EFFECTIVE MOISTURE DIFFUSIVITY, ACTIVATION ENERGY, ENERGY AND EXERGY ANALYSIS OF THIN LAYER DRYING OF PINEAPPLE
}

\author{
Sudharshan Reddy Ravula *1 ${ }^{1}$, Surender Reddy Munagala ${ }^{2}$, Divyasree Arepally ${ }^{3}$, Parabhaker Reddy \\ Ravula ${ }^{4}$, Sheshasayana Golla ${ }^{1}$
}

\footnotetext{
${ }^{1}$ Agricultural Processing and Food Engineering, CAE, ANGRAU, Bapatla, India

${ }^{2}$ Department of Food Technology, Osmania University, Hyderabad, India

${ }^{3}$ Agricultural and Food Engineering Department, Indian Institute of Technology, Kharagpur, West Bengal, India

${ }^{4}$ Department of Chemical Engineering, Rajiv Gandhi University of Knowledge Technologies (RGUKT), Basar, India
}

Received - May 07, 2017; Revision - May 29, 2017; Accepted - June 27, 2017

Available Online - June 30, 2017

DOI: http://dx.doi.org/10.18006/2017.5(3).392.401

\section{KEYWORDS}

Activation energy

Effective moisture diffusivity

Energy and Exergy analysis

\section{ABSTRACT}

The aim of the present study was to investigate the drying characteristics of pineapple at various temperatures of $55,60,65,70$ and $75{ }^{\circ} \mathrm{C}$ by keeping air velocity constant and best drying model was selected to describe the drying behaviour. Moreover, the energy requirement, exergy efficiency was also evaluated. Results of study revealed that the ascorbic acid content of dried pineapple was significantly reduced with increase in drying air temperatures. The effective moisture diffusivity, energy requirement and exergy efficiency during entire process of drying varied with the temperatures, in the range of $5.07 \times 10^{-10}$ to $1.18 \times 10^{-09} \mathrm{~m}^{2} / \mathrm{s}, 61.17$ to 28.85 $\mathrm{kWh} / \mathrm{kg}$ and 71.20 to $84.19 \%$, respectively. The activation energy for pineapple was found to be $38.83 \mathrm{~kJ} / \mathrm{mol}$.
* Corresponding author

E-mail: r.sudharshanreddy@gmail.com

Peer review under responsibility of Journal of Experimental Biology and Agricultural Sciences.

Production and Hosting by Horizon Publisher India [HPI] (http://www.horizonpublisherindia.in/).

All rights reserved.
All the article published by Journal of Experimental Biology and Agricultural Sciences is licensed under a Creative Commons Attribution-NonCommercial 4.0 International License Based on a work at www.jebas.org. 


\section{Introduction}

Pineapple (Ananas comosus) is one of the non citrus tropical and subtropical fruit, consumed all over the world because of its pleasant flavour and refreshing sugar-acid balance and it is also rich in minerals and vitamins (Bartolomé et al., 1995; Olanipekun et al., 2015). Pineapple is a seasonal and perishable fruit (due to higher moisture content), so that it is necessary to dehydrate it without change of nutritional and sensory characteristics to use in off season. Among all the available dryers methods, tray dryer is the most commonly used for drying of fruits and vegetables, but using high air temperature and longer drying time may lead to decrease in nutritional values and sensory characteristics. Dying process for agricultural material is mainly divided into two ways $v i z$., thin layer and deep bed layer drying. Thin-layer drying refers to the grain drying process in which all the grains are fully exposed to the drying air under constant drying condition, i.e. at constant air temperature and humidity. All commercial flow dryers are designed based on thin-layer drying principles (Chakraverty, 1994; Aghbashlo et al., 2008). Thus, thin-layer drying is the best method for the mathematical modelling and simulation of food drying process. In deep bed drying, the drying air moves from the lower zone to the upper zone of the bed so that bottom of bed dries rapidly. Moreover, there is temperature and humidity gradient between lower zone and upper zone of the bed. In deep bed drying, air temperature, air flow, and humidity of air mainly depends on the position of the material in the bed and drying time (Srivastava \& John, 2002).

Mathematical modelling and simulation of the drying process are used to improve new or existing drying system, to obtain better process control, and to achieve the better quality of the final product (Karathanos \& Belessiotis, 1999). Several investigations have been carried out on effective moisture diffusivity, activation energy by using Arrhenius equation, energy consumption and evaluation of different drying conditions in thin layer drying of different agricultural products such as pomace (Wang et al., 2007), apricot (Togrul \& Pehlivan, 2003), beriberi (Aghbashlo et al., 2008), fig (Babalis \& Belessiotis, 2004), grape (Yaldiz et al., 2001), organic apple (Sacilik \& Elicin, 2005), red chilli (Kaleemullah \& Kailappan, 2005) and tomato (Abano et al., 2011). Moisture diffusivity, which is mainly, depends on the internal material conditions and it is a major parameter in agricultural and food products, is required for modelling mass transfer processes such as surface absorption and moisture desorption during the storage period (Motevali et al., 2012). Now a days in any food industry, energy saving is a big challenging task to any researcher while maintain the quality. Therefore, it is required to reduce the energy consumption and provide optimum processing conditions for obtaining good quality product. Exergy analysis is an important tool for system design, analysis and optimization of thermal systems and it has been applied in various areas of engineering applications (Colak \& Hepbasli, 2007). The objective of the present research work was to select the suitable model to describe the thin layer drying of pineapple at various drying air temperatures, and to determine the effective moisture diffusivity, activation energy of pineapple by using Arrhenius equation, to analyse the energy requirement and energy efficiency.

\section{Materials and Methods}

\subsection{Drying procedure}

Pine apple (Ananas comosus) used for the drying experiments were procured from a local market. Prior to drying, the pineapple pointed ends were trimmed, peeled off, sliced into $10 \mathrm{~mm}$ thick. The drying experiments were performed in the hot air batch dryer which consisting of an air blower, heating section, temperature controller $\left(40-120{ }^{\circ} \mathrm{C}\right)$ and drying chamber. Prior to start the experiment, the dryer was preheated for approximately one hour to ensure equilibrium conditions with set temperatures and air velocity for each run. All experiments were operated at a temperature of $29 \pm 2^{\circ} \mathrm{C}$ and relative humidity of $55 \pm 2 \%$. About 100 $\mathrm{g}$ of the sliced pine apple samples were uniformly spread onto the cleaned rectangular aluminium perforated trays and kept in the dryer for drying at different air temperatures of 55, 60, 65, 70 and $75{ }^{\circ} \mathrm{C}$ with constant air velocity of $1.5 \mathrm{~m} / \mathrm{s}$. During the drying process, moisture loss was recorded in every $10 \mathrm{~min}$ intervals up to first $1 \mathrm{hr}$, later every $30 \mathrm{~min}$ intervals up to $2 \mathrm{hrs}$ followed by $1 \mathrm{hr}$ intervals by a digital balance of $\pm 0.001 \mathrm{~g}$ accuracy (Testing Instrument Pvt. Ltd., India) till a constant weight was achieved. Drying was stopped when the moisture content reached to 6-7\% (w.b.) from an initial value of $85.85 \pm 1.19 \%$ (w.b.). The dried product was kept in polythene covers for further processing. The drying process was carried out for all runs with three replications and the average values were taken.

\subsection{Determination of Ascorbic acid}

For determining the Vitamin $\mathrm{C}$ content, initially, dried samples were grinded to make into powder. The samples were sieved through the $150 \mu \mathrm{m}$ sieve and retained sample over the sieve was discarded. Vitamin C content was estimated by volumetric method (Sadasivam \& Manickam, 1992). Exactly $5 \mathrm{ml}$ of the working standard solution was taken into a $100 \mathrm{ml}$ conical flask, to this 10 $\mathrm{ml}$ of $4 \%$ oxalic acid was added and this was turned to pink colour end point when titrated against the dye solution $\left(\mathrm{V}_{1} \mathrm{ml}\right)$. The amount of the dye consumed was equivalent to the amount of ascorbic acid. One gram of fine pine apple powder sample was weighed and crushed using $4 \%$ oxalic acid. The extract was filtered through Whatman No. 41 filter paper and made the volume up to $100 \mathrm{ml}$. Five $\mathrm{ml}$ of the extract was taken into conical flask, $10 \mathrm{ml}$ of $4 \%$ oxalic acid was added and was titrated against the dye $\left(\mathrm{V}_{2} \mathrm{ml}\right)$ (Sadasivam \& Manickam,1992). Determination of vitamin $\mathrm{C}$ content of samples was carried out thrice and the average value was considered as vitamin $\mathrm{C}$ content of powdered pine apple. 


\section{Mathematical Modelling}

Mathematical modelling of thin layer drying is an essential tool to predict and simulate the drying behaviour, and contributing to better understanding of the drying mechanism. The experimental data of moisture ratio (MR) and time (t) were fitted to different empirical drying models. The non linear regression analysis was performed using curve fitting tool in MATLAB software package (R2015a (8.5.0.197613)) to determine the drying rate constants and coefficients of the model equations as well as to select the best fit model that describes the drying characteristics or behaviour of the material. Comparison criteria were used to estimate the goodness of fit for selected models in thin layer drying based on lower root mean square error (RMSE), reduced chi-square $\chi^{2}$ and higher coefficient of determination $\mathrm{R}^{2}$. Several authors have been used these criteria to select the best models for drying of biological materials such as tomato (Abano et al., 2011), beriberi (Aghbashlo et al., 2008), apple pomace (Wang et al., 2007), fig (Babalis \& Belessiotis, 2004), pineapple (Reddy et al., 2017) and grape (Yaldiz et al., 2001). The different statistical evaluation (Equations 1,2 , and 3) to describe the goodness of fit of the dried pineapple slices are as follows:

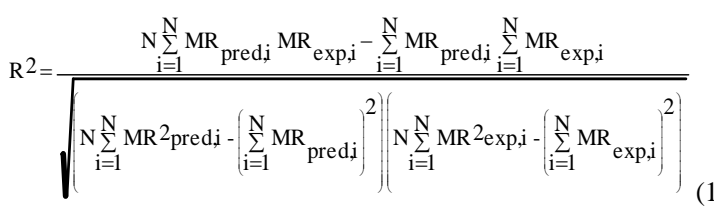

$\operatorname{RMSE}=\left[\frac{1}{\mathrm{~N}} \sum_{\mathrm{i}=1}^{\mathrm{N}}\left(\mathrm{MR}_{\text {predi }}-\mathrm{MR}_{\text {exp.i }}\right]^{1 / 2}\right.$

$\chi^{2}=\frac{\sum_{i=1}^{N}\left(M R_{\exp , i}-M R_{\text {pred }, i}\right)^{2}}{N-S}$

Where $M R_{\text {expt }}$, and $M R_{\text {pred }}$ are the $i^{\text {th }}$ experimental $M R$ and $i^{\text {th }}$ predicted $\mathrm{MR}, \mathrm{N}$ is the number of observations, and $\mathrm{S}$ is the number of model constants.

The dimensionless moisture ratio (MR) was computed from equation 4 for the five different drying air temperatures $(55,60,65$, 70 and $75^{\circ} \mathrm{C}$ ) and was plotted against drying time.

$\mathrm{MR}=\frac{\mathrm{M}_{\mathrm{t}}-\mathrm{M}_{\mathrm{e}}}{\mathrm{M}_{0}-\mathrm{M}_{\mathrm{e}}}$

Where, MR is the moisture ratio (dimensionless), $\mathrm{M}$ is the moisture content ( $\mathrm{kg}$ water. $\mathrm{kg}$ dry matter ${ }^{-1}$ ) at any time in time ( $\mathrm{t}$ ) and $\mathrm{M}_{\mathrm{e}}$ is the equilibrium moisture content ( $\mathrm{kg}$ water.kg dry matter ${ }^{-1}$ ), and $\mathrm{M}_{0}$ is the initial moisture content ( $\mathrm{kg}$ water. $\mathrm{kg}$ dry matter $\left.{ }^{-1}\right)$. During experiments, the $\mathrm{M}_{\mathrm{e}}$ was not determined and since this value is relatively small compared to $\mathrm{M}_{\mathrm{t}}$ or $\mathrm{M}_{0}$ (Kingsly et al., 2007; Doymaz, 2007), so the $\mathrm{M}_{\mathrm{e}}$ was assumed to be zero.
Hence, the moisture ratio was simplified according to reported by Pala et al. (1996) and Kingsly et al. (2007):

$$
\mathrm{MR}=\frac{\mathrm{M}}{\mathrm{M}_{0}}
$$

The drying curves were then plotted with the recorded moisture contents for each sample at different drying air temperatures. The drying rate of pineapple slices was calculated using following equation:

$$
\mathrm{DR}=\frac{\mathrm{M}_{\mathrm{t}}+\mathrm{dt}-\mathrm{M}_{\mathrm{t}}}{\mathrm{dt}}
$$

Where, $\mathrm{M}_{\mathrm{t}+\mathrm{dt}}$ is the moisture content ( $\mathrm{kg}$ water. $\mathrm{kg}$ dry matter ${ }^{-1}$ ) at $\mathrm{t}$ $+\mathrm{dt}$, and $\mathrm{t}$ is the drying time ( $\mathrm{min})$.

\subsection{Estimation of effective moisture diffusivity and activation energy}

The complete drying profile can be divided into two stages a constant rate period, and a falling rate period in which moisture transfer within the food is mainly by molecular diffusion (Bon et al., 1997). During drying, diffusion is a complex process that may involve, molecular diffusion, capillary flow, Knudsen flow, hydrodynamic flow, or surface diffusion, if combine these process in to one the effective diffusion can be defined from Fick's second law (Mujumdar, 2014) as given below

$$
\frac{\partial \mathrm{M}}{\partial t}=\mathrm{D}_{\mathrm{eff}} \nabla^{2} \mathrm{M}
$$

Where $\mathrm{M}=$ moisture content $(\mathrm{kg}$ water $/ \mathrm{kg}$ dry matter)

The above equation indicates the rate of change in moisture transfer within the solid. The effective moisture diffusivity was estimated by using analytical solution of Fick's second law for unsteady state diffusion. The falling rate period of biological materials is best described by Fick's second law of diffusion (Crank, 1975; Roberts et al. 2008). The analytical solution of above equation is solved by considering pineapple slice as an infinite slab geometry, assuming uniform initial moisture distribution, constant temperature and diffusivity coefficient, and negligible external mass transfer resistance (Crank, 1975; Doymaz, 2007). The solution for above equation is of form:

$$
\mathrm{MR}=\frac{\mathrm{M}}{\mathrm{M}_{0}}=\frac{8}{\pi^{2}} \sum_{\mathrm{n}=1}^{\infty} \frac{1}{(2 \mathrm{n}-1)^{2}} \exp \left(-\frac{(2 \mathrm{n}-1)^{2} \pi^{2} \mathrm{D}_{\text {eff }} \mathrm{t}}{4 \mathrm{~L}^{2}}\right)
$$

For long drying time and for rectangular geometry, the equation is simplified to following equation (Akpinar, 2006; Doymaz, 2007).

$$
\mathrm{MR}=\frac{\mathrm{M}}{\mathrm{M}_{0}}=\frac{8}{\pi^{2}} \exp \left(\frac{-\mathrm{D}_{\mathrm{eff}} \pi^{2} \mathrm{t}}{4 \mathrm{~L}^{2}}\right)
$$

Where, $D_{\text {eff }}$ is effective moisture diffusivity $\left(\mathrm{m}^{2} / \mathrm{s}\right), t$ is drying time (s) and $\mathrm{L}$ is half the thickness of the sample slice (m). The graph of lnMR against drying time was plotted to obtain the $D_{\text {eff }}$ and the $D_{\text {eff }}$ is calculated from the following expression:

$\mathrm{m}=\frac{\pi^{2} \mathrm{D}_{\text {eff }}}{4 \mathrm{~L}^{2}}$

The activation energy for moisture diffusion was computed using Arrhenius equation (Babalis \& Belessiotis, 2004) from expression given below 


$$
\mathrm{D}_{\text {eff }}=\mathrm{D}_{0} \exp \left[-\frac{\mathrm{E}_{\mathrm{a}}}{\mathrm{RT}}\right]
$$

Where $D_{o}$ is the constant $\left(\mathrm{m}^{2} / \mathrm{s}\right)$, Ea is the activ ation energy $(\mathrm{kJ}$ $\left.\mathrm{mol}^{-1}\right), \mathrm{T}$ is the temperature of hot air $\left({ }^{\circ} \mathrm{C}\right)$, and $\mathrm{R}$ is the universal gas constant $\left(8.314 \mathrm{~J} \mathrm{~mol}^{-1} \mathrm{~K}^{-1}\right)$.

$$
\ln \mathrm{D}_{\mathrm{eff}}=\ln \mathrm{D}_{0}-\frac{\mathrm{E}_{\mathrm{a}}}{\mathrm{RT}}
$$

From above equation, it is clearly understood that the graph of $1 \mathrm{nD}_{\text {eff }}$ was plotted against $1 / \mathrm{T}$ and the activation energy was obtained from the slope of the curve (i.e. slope $=E_{a} / R$ ) and the intercept equals the $\operatorname{lnD}_{0}$ (Togrul \& Pehlivan, 2003; Aghbashlo et al., 2008).

\subsection{Energy consumption}

During the drying experiment, the total energy requirement and the specific energy consumption for drying of $1 \mathrm{~kg}$ of pineapple slices was computed according to Koyuncu et al. (2007) and Aghbashlo et al. (2008) for different air temperatures using the following equations:

$$
E_{t}=A v_{a} \rho_{a} C_{p} \Delta t D_{t}
$$

Where, $\mathrm{E}_{t}$ is the total energy requirement $(\mathrm{kW} \mathrm{h})$

A is the cross sectional area of the tray $\left(\mathrm{m}^{2}\right)$

$\mathrm{v}_{\mathrm{a}}$ is the velocity of air $(\mathrm{m} / \mathrm{s})$

$\rho_{\mathrm{a}}$ is the air density $\left(\mathrm{kg} \mathrm{m}^{-3}\right)$

$\mathrm{C}_{\mathrm{p}}$ is the specific heat of air under adiabatic conditions $\left(\mathrm{kJ} \mathrm{kg}^{-1} \mathrm{~K}^{-1}\right)$ $\Delta \mathrm{T}$ is the temperature differences between inlet and outlet of the dryer $\left({ }^{\circ} \mathrm{C}\right)$

$\mathrm{D}_{\mathrm{t}}$ is the total drying time $(\mathrm{h})$ and

Specific energy consumption for drying of one kilogram of pineapple was determined by following equation

$$
\mathrm{E}_{\mathrm{sp}}=\frac{\mathrm{E}_{\mathrm{t}}}{\mathrm{W}_{\mathrm{i}}}
$$

Where, $\mathrm{E}_{\mathrm{sp}}$ is the specific energy consumption $(\mathrm{kW} \mathrm{h} / \mathrm{kg})$, and $\mathrm{W}_{\mathrm{i}}$ is the initial weight of product in $\mathrm{kg}$.

\subsection{Exergy efficiency}

The second law of thermodynamic states that part of the exergy entering a thermal system is destroyed within the system due to irreversibilities (Avira et al., 2014). Based on the principle of second law of thermodynamic, the exergy analysis of the any drying process is performed. The exergy values are determined at steady-state points by using the working medium properties from the first law energy balance. For this purpose, the mathematical formulations used to carry out the exergy balance are as given in the following equations (Avira et al., 2014).

Exergy $=e-e_{\infty}-T_{\infty}\left(E-E_{\infty}\right)+p_{\infty}\left(w-w_{\infty}\right)+\frac{v^{2}}{2}+\left(g-g_{\infty}\right) g+v\left(p-p_{\infty}\right)$

\section{Where}

$\infty$ denotes the reference conditions

Exergy is expressed in $\mathrm{J} / \mathrm{kg}$,

$\mathrm{e}-\mathrm{e}_{\infty}$ is internal energy component in $\mathrm{J} / \mathrm{kg}$,
$\mathrm{T}_{\infty}$ is ambient temperature in ${ }^{\circ} \mathrm{C}$,

$\mathrm{E}-\mathrm{E}_{\infty}$ is entropic component in $\mathrm{J} / \mathrm{kg}$,

$\mathrm{p}_{\infty}\left(\mathrm{W}-\mathrm{W}_{\infty}\right)$ is work component in $\mathrm{J} / \mathrm{kg}$,

$\mathrm{V}^{2} / 2$ is the momentum component in $\mathrm{J} / \mathrm{kg}$ and

$\left(\mathrm{g}-\mathrm{g}_{\infty}\right) \mathrm{g}$ is gravity component in $\mathrm{J} / \mathrm{kg}$,

In the above equation, only some of the terms are used and momentum, gravity and pressure changes terms are neglected in the system since there is no lifting and no relative motion during drying process. Therefore, the final equation becomes to compute the inflow and out flow of exregy that depending on the inlet and outlet temperatures of the drying chamber as follows:

$$
\text { Exergy }=\left[\mathrm{C}_{\text {pair }}\left[\left(\mathrm{T}-\mathrm{T}_{\infty}\right)\right]-\mathrm{T}_{\infty} \ln \frac{\mathrm{T}}{\mathrm{T}_{\infty}}\right]
$$

Exergy loss can be calculated by using following expression:

$$
\text { Exergy loss }=\mathrm{EX}_{\mathrm{i}}-\mathrm{EX}_{\mathrm{o}}
$$

Exergy inflow and outflow for the drying chamber was calculated using following equations

$$
\begin{aligned}
& \text { Exergy inflow }\left(\mathrm{EX}_{\mathrm{i}}\right)=\mathrm{C}_{\text {pair }}\left[\left[\left(\mathrm{T}_{\text {inlet air }}-\mathrm{T}_{\infty}\right)\right]-\mathrm{T}_{\infty} \ln \frac{\mathrm{T}_{\text {inlet air }}}{\mathrm{T}_{\infty}}\right] \\
& \text { Exergy out flow }\left(\mathrm{EX}_{\mathrm{O}}\right)=\mathrm{C}_{\text {pair }}\left[\left[\left(\mathrm{T}_{\text {outletair }}-\mathrm{T}_{\infty}\right)\right]-\mathrm{T}_{\infty} \ln \frac{\mathrm{T}_{\text {outlet air }}}{\mathrm{T}_{\infty}}\right]
\end{aligned}
$$

Exergy efficiency can be defined as the ratio of product exergy to exergy inflow to drying chamber and it can be expressed (Colak and Hepbasli, 2007; Avira et al., 2014) as

$$
\begin{aligned}
& \text { Exergy efficiency }\left(\eta_{\mathrm{Ex}}\right)=\frac{\mathrm{EX}_{\mathrm{i}}-\mathrm{EX}_{\mathrm{O}}}{\mathrm{EX}_{\mathrm{i}}} \\
& \eta_{\mathrm{Ex}}=\frac{\mathrm{EX}_{\mathbf{i}}-\mathrm{EX}_{\text {loss }}}{\mathrm{EX}_{\mathbf{i}}}
\end{aligned}
$$

\section{Results and discussion}

The drying process was done from initial moisture content $(85.85 \pm 1.19$ w.b.) of pine apple slices to final moisture contents of less than $7 \mathrm{~kg}$ water.kg dry matter ${ }^{-1}$ in convective dryer with different air temperatures of $55,60,65,70$ and $75^{\circ} \mathrm{C}$. It is clearly seen from the Figure 1, moisture content reduced expontially as the

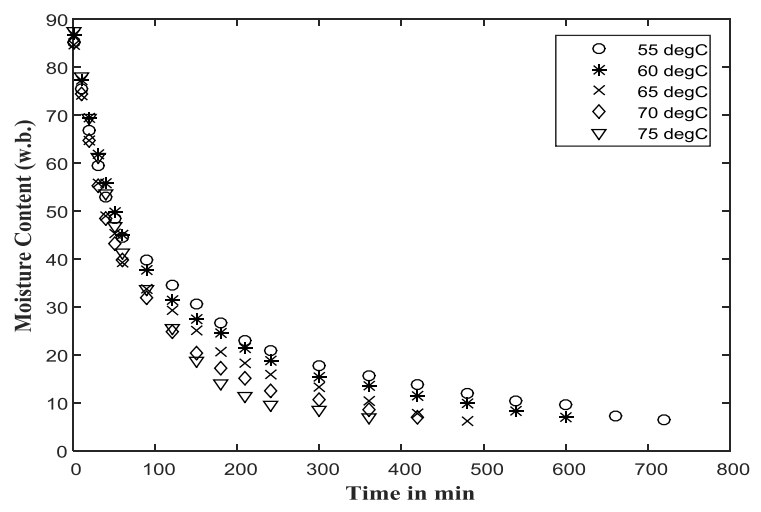

Figure 1 Plot of moisture ratio versus drying time at various drying air temperatures 


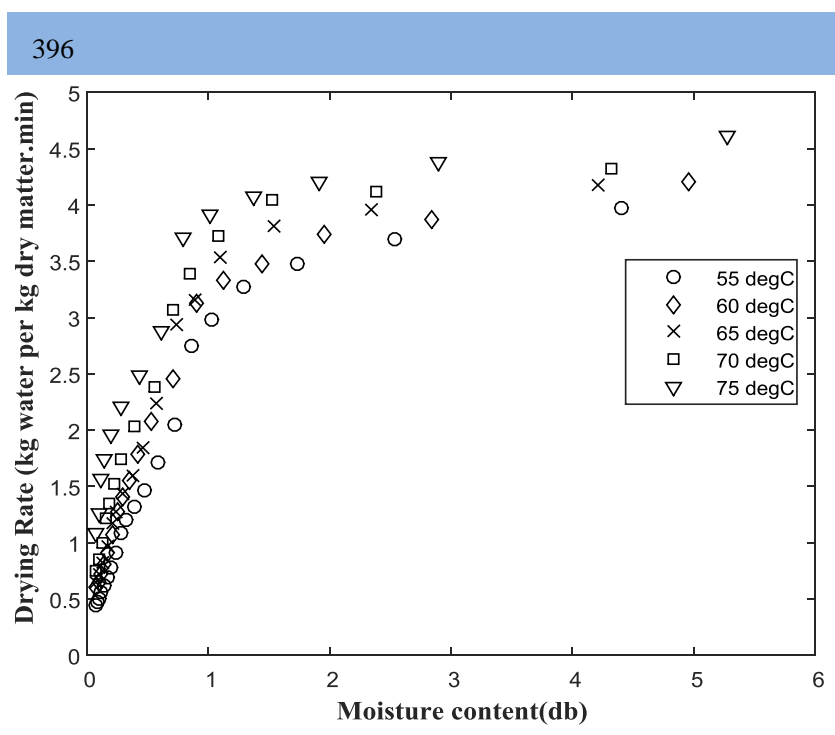

Figure 2 Plot of drying rate and moisture content (d.b) at different ait temperatures for thin layer drying of pineapple

drying time increased at all drying air temperatures when the air velocity was kept constant. It was observed that this continuously decrease in moisture content indicating that moisture diffusion had governed the internal mass transfer. Moreover, it could be observed that the increase in drying air temperature reduced the drying time.

From Figure 2, it is shown, the drying rate increased with increasing in drying air temperature, due to higher temperature gradient between samples and drying air that increases the heat transfer coefficient which influences the heat and mass transfer rate. Furthermore, the drying process was occurred in falling rate period, as there is no constant drying rate period in drying of pineapple slices at all drying conditions, indicating that diffusion had governed the internal mass transfer. These results are in agreement with several authors for drying of mango fruit (Goyal et al., 2006), apple (Sacilik \& Elicin, 2006) and for some other fruits and vegetables (Akpinar, 2006; Akanbi et al., 2006), but Diamante et al. (2010) found that the drying of green and gold kiwifruit slices consists of a constant rate period and two parts of falling rate period and Chen et al. (2001) also reported that the drying of green kiwifruit puree consists of a constant rate period and only one falling rate period.

\subsection{Effect of drying air temperature on Ascorbic acid}

The effect of drying air temperature on the ascorbic acid is
Ravula et al

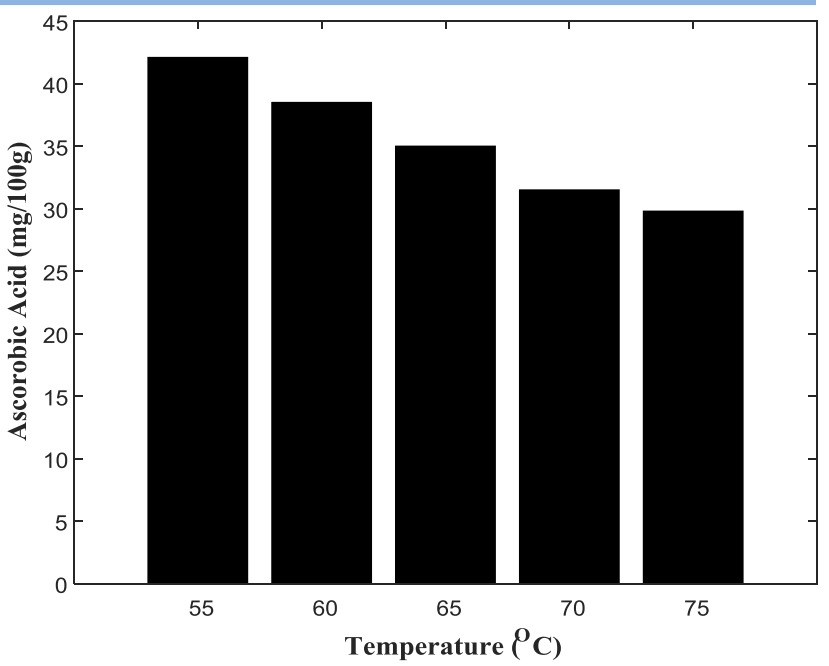

Figure 3 Effect of drying air temperature on ascorbic acid content in dried pineapple powder

depicted in Figure 3. It was observed that increasing drying air temperature increases degradation of vitamin $\mathrm{C}$ in the dried sample. The ascorbic acid was more at the temperature of $55^{\circ} \mathrm{C}$ whereas less at $75{ }^{\circ} \mathrm{C}$. These results are in consistent with previous reports by Santos \& Silva (2009) for pineapple and Kaya et al. (2010) for kiwi fruit. Moreover, it is observed from the results, the temperature effect on vitamin $\mathrm{C}$ was more important than the time effect on the ascorbic acid degradation during drying process.

\subsection{Mathematical modelling}

The dimensionless moisture ratio against drying time at different air temperatures was fitted to the 6 thin layer drying models (Table1). The relatively high values of correlation coefficients $\left(\mathrm{R}^{2}\right)$, lowest chi-square $\left(\chi^{2}\right)$, and low root mean square errors (RMSE) indicate the selection of the best model describing the thin layer drying kinetics for the temperature tested over the entire duration of the drying process. According to the different experimental conditions, the correlation coefficient, RMSE and chi-square varied between $0.9995-0.9270,0.0070-0.0891$ and $4.85 \times 10^{-05}-1.08 \times 10^{-03}$ for all examined models, respectively. The regression results to experimental data is presented in Table 2, it was observed that the best statistical values given for the Verma et al. (1985) based on comparison criteria to represent the thin-layer drying behaviour of pine apple. The highest correlation coefficient, lowest RMSE as well as chi-square values were ranged from

Table 1 Mathematical models applied to drying kinetics

\begin{tabular}{|cccc|}
\hline Sl. No & Model & Expression & References \\
\hline 1 & Logarthamic & a exp(-kt)+c & Akpinar (2006) \\
\hline 2 & Modified Page & $\exp (-(\mathrm{kt}) \wedge \mathrm{n})$ & Yaldiz et al. (2001) \\
\hline 3 & Newton model & $\exp (-\mathrm{kt})$ & Westerman et al. (1973) \\
\hline 4 & Page model & $\exp \left(-\mathrm{kt} \mathrm{n}^{\mathrm{n}}\right)$ & Page (1949) \\
\hline 5 & Two term exponential & a $\exp (-\mathrm{kt})+(1-\mathrm{a}) \exp (-\mathrm{kat})$ & Yaldiz et al. (2001) \\
\hline 6 & Verma et al & A $\exp (-\mathrm{kt})+(1-\mathrm{a}) \exp (-\mathrm{gt})$ & Verma et al. (1985) \\
\hline
\end{tabular}

Journal of Experimental Biology and Agriculture Science

http://www.jebas.org 
Table 2 Statistical parameters and model constants at different drying temperatures

\begin{tabular}{|c|c|c|c|c|c|}
\hline \multicolumn{6}{|c|}{ MODELS AT $55^{\circ} \mathrm{C}$} \\
\hline SL NO & Model & R-squared & RMSE & Reduced Chi square & Parameters \\
\hline 1 & Logarthamic model & 0.9808 & 0.0405 & $1.64 \mathrm{E}-03$ & $\mathrm{a}=0.7934 ; \mathrm{c}=0.1292 ; \mathrm{k}=0.00935$ \\
\hline 2 & Modified page & 0.9944 & 0.0213 & $4.56 \mathrm{E}-04$ & $\mathrm{k}=0.006862 ; \mathrm{n}=0.6124$ \\
\hline 3 & Newton model & 0.8968 & 0.0891 & $7.95 \mathrm{E}-03$ & $\mathrm{k}=0.007208$ \\
\hline 4 & Page model & 0.9944 & 0.0213 & $4.56 \mathrm{E}-04$ & $\mathrm{k}=0.04732 ; \mathrm{n}=0.6124$ \\
\hline 5 & Two term exponential & 0.9491 & 0.0642 & $4.12 \mathrm{E}-03$ & $\mathrm{a}=0.1996 ; \mathrm{k}=0.02737$ \\
\hline 6 & Verma et al. & 0.9981 & 0.0127 & 1.61E-04 & $\mathrm{a}=0.495 ; \mathrm{g}=0.002723 ; \mathrm{k}=0.0255$ \\
\hline \multicolumn{6}{|c|}{ MODELS AT $60^{\circ} \mathrm{C}$} \\
\hline SL NO & Model & R-squared & RMSE & Reduced Chi square & Parameters \\
\hline 1 & Logarthamic model & 0.9897 & 0.0310 & $9.59 \mathrm{E}-04$ & $\mathrm{a}=0.8324 ; \mathrm{c}=0.1275 ; \mathrm{k}=0.0109$ \\
\hline 2 & Modified page & 0.9925 & 0.0256 & $6.54 \mathrm{E}-04$ & $\mathrm{k}=0.007655 ; \mathrm{n}=0.6728$ \\
\hline 3 & Newton model & 0.9324 & 0.0748 & $5.59 \mathrm{E}-03$ & $\mathrm{k}=0.008041$ \\
\hline 4 & Page model & 0.9925 & 0.0256 & $6.54 \mathrm{E}-04$ & $\mathrm{k}=0.0377 ; \quad \mathrm{n}=0.6728$ \\
\hline 5 & Two term exponential & 0.9715 & 0.0499 & $2.49 \mathrm{E}-03$ & $\mathrm{a}=0.2179 ; \quad \mathrm{k}=0.02759$ \\
\hline 6 & Verma et al. & 0.9995 & 0.0070 & 4.85E-05 & $\mathrm{a}=0.4358 ; \mathrm{g}=0.0204 ; \mathrm{k}=0.00283$ \\
\hline \multicolumn{6}{|c|}{ MODELS AT $65^{\circ} \mathrm{C}$} \\
\hline SI NO & Model & R-squared & RMSE & Reduced Chi square & Parameters \\
\hline 1 & Logarthamic model & 0.9897 & 0.0310 & $9.59 \mathrm{E}-04$ & $\mathrm{a}=0.8324 ; \mathrm{c}=0.1276 ; \mathrm{k}=0.01091$ \\
\hline 2 & Modified page & 0.9936 & 0.0235 & $5.51 \mathrm{E}-04$ & $\mathrm{k}=0.009179 ; \quad \mathrm{n}=0.6717$ \\
\hline 3 & Newton model & 0.9290 & 0.0757 & $5.72 \mathrm{E}-03$ & $\mathrm{k}=0.009541$ \\
\hline 4 & Page model & 0.9936 & 0.0235 & $5.51 \mathrm{E}-04$ & $\mathrm{k}=0.04281 ; \mathrm{n}=0.6717$ \\
\hline 5 & Two term exponential & 0.9722 & 0.0489 & $2.39 \mathrm{E}-03$ & $\mathrm{a}=0.2087 ; \quad \mathrm{k}=0.03459$ \\
\hline 6 & Verma et al. & 0.9983 & 0.0126 & $1.58 \mathrm{E}-04$ & $\mathrm{a}=0.5216 ; \mathrm{g}=0.0294 ; \mathrm{k}=0.00412$ \\
\hline \multicolumn{6}{|c|}{ MODELS AT $70^{\circ} \mathrm{C}$} \\
\hline SI NO & Model & R-squared & RMSE & Reduced Chi square & Parameters \\
\hline 1 & Logarthamic model & 0.9945 & 0.0232 & $5.39 \mathrm{E}-04$ & $\mathrm{a}=0.8586 ; \mathrm{c}=0.1179 ; \mathrm{k}=0.01451$ \\
\hline 2 & Modified page & 0.9939 & 0.0236 & $5.55 \mathrm{E}-04$ & $\mathrm{k}=0.01047 ; \mathrm{n}=0.72$ \\
\hline 3 & Newton model & 0.9538 & 0.0626 & $3.92 \mathrm{E}-03$ & $\mathrm{k}=0.01087$ \\
\hline 4 & Page model & 0.9939 & 0.0236 & $5.55 \mathrm{E}-04$ & $\mathrm{k}=0.03752 ; \quad \mathrm{n}=0.72$ \\
\hline 5 & Two term exponential & 0.9843 & 0.0377 & $1.42 \mathrm{E}-03$ & $\mathrm{a}=0.2294 ; \mathrm{k}=0.03523$ \\
\hline 6 & Verma et al. & 0.9994 & 0.0079 & 6.17E-05 & $\mathrm{a}=0.6091 ; \mathrm{g}=0.00383 ; \mathrm{k}=0.0227$ \\
\hline \multicolumn{6}{|c|}{ MODELS AT $75^{\circ} \mathrm{C}$} \\
\hline SI NO & Model & R-squared & $\overline{\text { RMSE }}$ & Reduced Chi square & Parameters \\
\hline 1 & Logarthamic model & 0.9984 & 0.013397 & $1.79 \mathrm{E}-04$ & $\mathrm{a}=0.9199 ; \mathrm{c}=0.07802 \quad \mathrm{k}=0.0132$ \\
\hline 2 & Modified page & 0.9955 & 0.021547 & 4.64E-04 & $\mathrm{k}=0.01076 ; \mathrm{n}=0.8577$ \\
\hline 3 & Newton model & 0.9876 & 0.034612 & $1.20 \mathrm{E}-03$ & $\mathrm{a}=0.00819 ; \mathrm{b}=0.02366$ \\
\hline 4 & Page model & 0.9955 & 0.021547 & 4.64E-04 & $\mathrm{k}=0.0205 ; \mathrm{n}=0.8577$ \\
\hline 5 & Two term exponential & 0.9967 & 0.01863 & $3.47 \mathrm{E}-04$ & $\mathrm{a}=0.3122 ; \mathrm{k}=0.02512$ \\
\hline 6 & Verma et al. & 0.9985 & 0.01284 & $1.65 \mathrm{E}-04$ & $\mathrm{a}=0.8532 ; \mathrm{g}=0.001979 ; \mathrm{k}=0.0143$ \\
\hline
\end{tabular}

0.9995 to 0.9981 and 0.0070 to 0.0128 and $6.17 \times 10^{-05}$ to $1.58 \times 10^{-}$ ${ }^{04}$ for Verma et al. (1985), respectively and these values are superior to other models. It is clear from the Table 2, drying air temperature of $60{ }^{\circ} \mathrm{C}$ gave the highest value of correlation coefficients as well as the lowest value of RMSE and chi-square. As shown in Figure 7 (a \& b) for temperatures of 55 and $65{ }^{\circ} \mathrm{C}$, the obtained values of predicted MR from Verma et al. (1985) were found to be good agreement with the experimental MR. It could be explained that the experimental MR values were closely bound to the predicted MR values. These values are laid around the straight line. Similar trend was obtained for remaining temperatures (Figures are not shown). Moreover, it was also observed from Figures 8, obtained predicted MR from Verma et al. (1985) was good consistency with experimental data when plotted against drying time at all temperatures. 


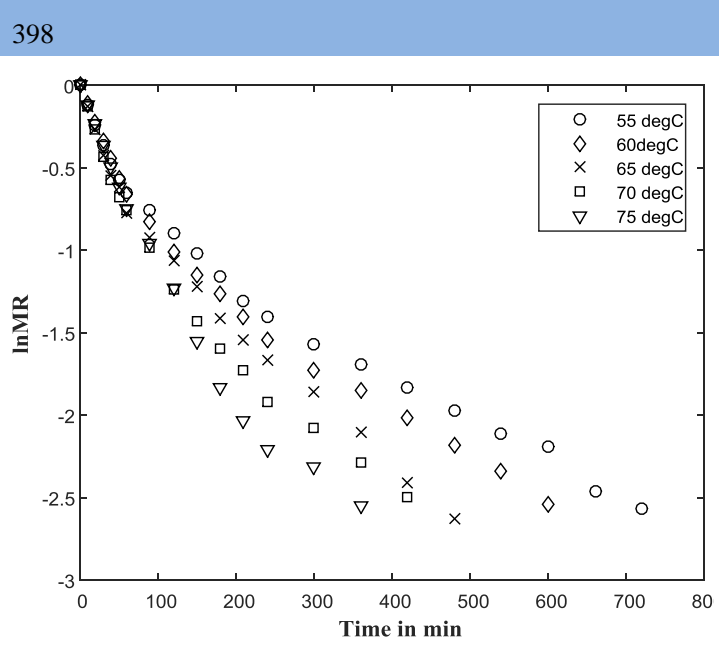

Figure 4 Plot of lnMR against drying time at various drying air

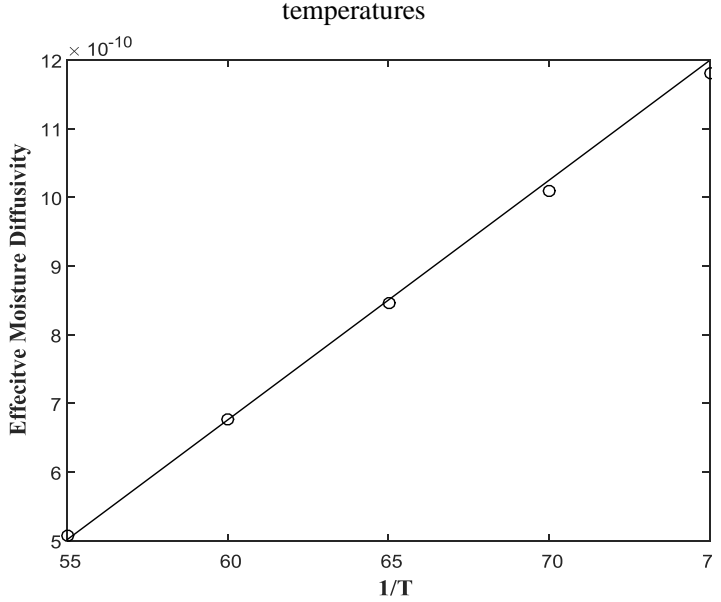

Figure 5 Effective moisture diffusivity as a function of drying air temperatures

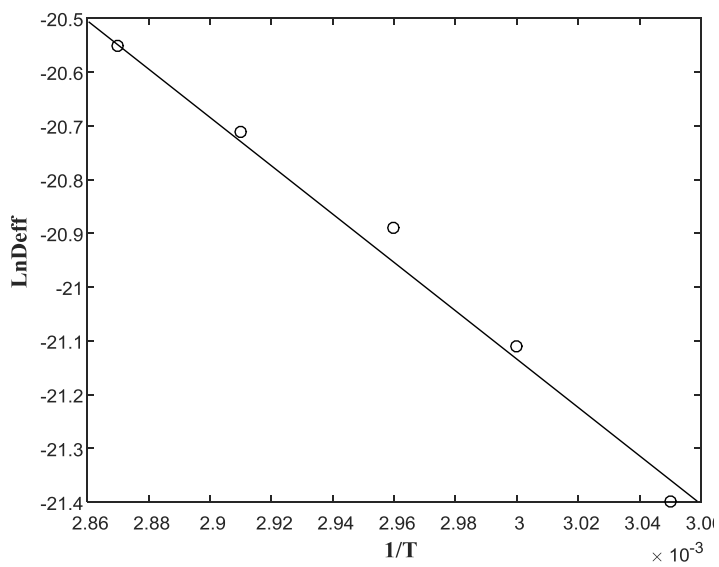

Figure 6 Plot of LnDeff against reciprocal of temperature $(1 / T)$ estimation of activation energy

\subsection{Effective moisture diffusivity}

The effective moisture diffusivity was calculated by using the slope method, plotting the lnMR against the drying time as shown in Figure 4. In the present work, the values of $D_{\text {eff }}$ obtained for
Ravula et al

pineapple varied from $5.07 \times 10^{-10}$ at $55^{\circ} \mathrm{C}$ to $1.18 \times 10^{-09} \mathrm{~m}^{2} / \mathrm{s}$ in the range of 55 to $75{ }^{\circ} \mathrm{C}$. These diffusivity values were good agreement with reported for most of the fruits and vegetables, $6.89 \times 10^{-10}$ to $5.10 \times 10^{-08} \mathrm{~m}^{2} / \mathrm{s}$ for pineapple dried from 50 to $70{ }^{\circ} \mathrm{C}$ (Olanipekun et al., 2015), and 1.743 to $2.241 \times 10^{-10} \mathrm{~m}^{2} / \mathrm{s}$ for kiwi fruit dried from 50 to $60{ }^{\circ} \mathrm{C}$ (Doymaz, 2007). In general, the values of effective diffusivity fall within the range of $10^{-11}$ to $10^{-6}$ for all agricultural and food products (Wang et al., 2007; Aghbashlo et al., 2008). It is evident from Figure 5 the moisture diffusivity was increased with increase in temperature range of 55 to $75{ }^{\circ} \mathrm{C}$. The reason might be due to the greater absorption of moisture, which increases the moisture gradient between the sample and the ambient air conditions. These results were similar to that the reports of Aghbashlo et al. (2008) for beriberi fruit, Kaleemullah \& Kailappan (2005) for red chillies and others. In the present work, the authors developed the following regression equation $\left(R^{2}=0.9741\right)$ for moisture diffusivity as a function of moisture content (wet basis) and drying air temperature $\left({ }^{\circ} \mathrm{C}\right)$.

$\mathrm{D}=-1.241 \mathrm{e}-14 * \mathrm{M}^{\wedge} 2+3.86 \mathrm{e}-13 * \mathrm{~T}^{\wedge} 2+7.085 \mathrm{e}-12 * \mathrm{M}-1.305 \mathrm{e}-11 * \mathrm{~T}-$ $9.212 \mathrm{e}-14 * \mathrm{M} * \mathrm{~T}+2.797 \mathrm{e}-11$

\subsection{Activation energy}

The $1 n D_{\text {eff }}$ against the reciprocal of temperature was plotted to calculate the activation energy as shown in Figure 6. In present work, the activation energy was $38.83 \mathrm{~kJ} / \mathrm{mol}$. These obtained $\mathrm{E}_{\mathrm{a}}$ value for pineapple was within the range of $12.7-110 \mathrm{~kJ} / \mathrm{mol}$ for high moisture agricultural and food materials (Babalis \& Belessiotis, 2004; Aghbashlo et al., 2008). In the present study, activation energy values are greatly compared with the 30.14 $\mathrm{kJ} / \mathrm{mol}$ for apricot (Mirzaee et al., 2009) and 30.81-48.47 kJ/mol for Fig (Babalis \& Belessiotis, 2004). In general, lower the activation energy, lesser the energy required to initiate moisture diffusion from integral parts of material to surface of the material (Olanipekun et al., 2015).

\subsection{Energy consumption and Exergy efficiency}

Energy consumption for drying of one kilogram of fresh pineapple was calculated from equations 13 and 14. The maximum (61.17 $\mathrm{kWh} / \mathrm{kg})$ and minimum energy $(28.85 \mathrm{kWh} / \mathrm{kg})$ consumption was obtained at a temperature of $55{ }^{\circ} \mathrm{C}$ and $75{ }^{\circ} \mathrm{C}$, respectively. It is evident from Figure 9, the energy consumption decreased with increase in drying air temperature; the reason may be due to the air temperature. The similar trend was observed by Aghbashlo et al. (2008) for beriberi fruit and Koyuncu et al. (2007) for cherry fruit. There was an increase in exergy inflow, outflow and losses from 2.26 to $5.42,1.61$ to 4.56 and $0.65-0.85 \mathrm{~J} / \mathrm{s}$, respectively, with increase in air temperature from 55 to $75{ }^{\circ} \mathrm{C}$. The obtained results were good consistent with data reported by Corzo et al. (2008) for Coroba slice drying, Aviara et al. (2014) for cassava starch drying, lesser time required for drying of product with increase in drying and Erbay \& Icier (2011) for olive leaves drying. The variation in exergy efficiency with respect to temperature is inversely to the 

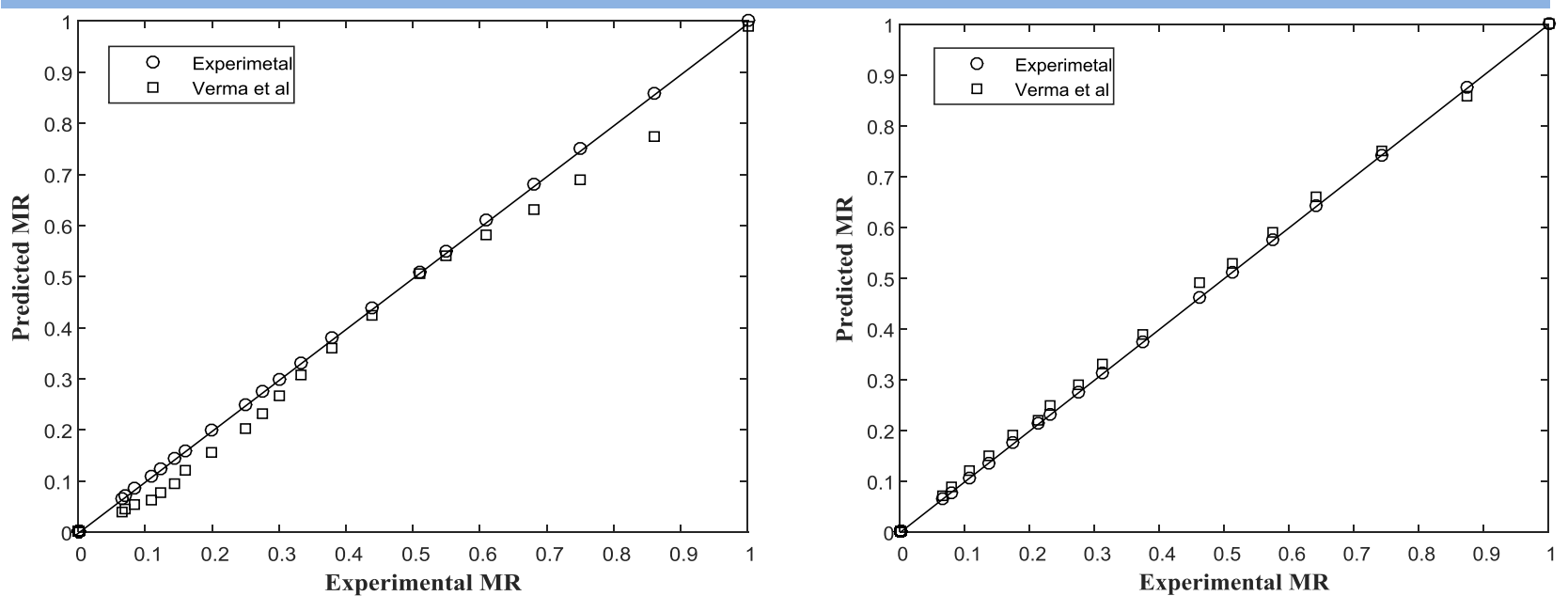

Figure 7 Plot of experimental data against predicted data obtained from COMSOL and Verma et al (1985) at the temperature of 55 and $65{ }^{\circ} \mathrm{C}$

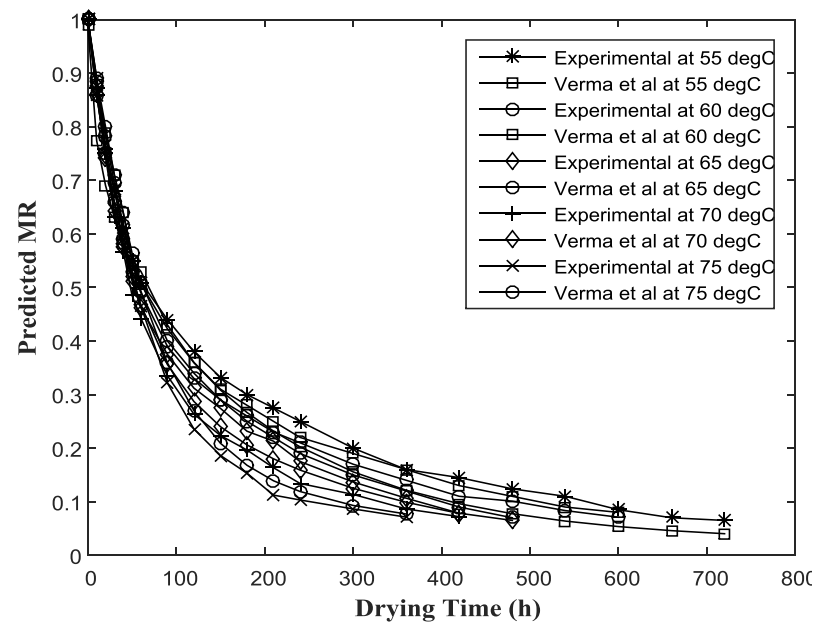

Figure 8 Plot of experimental MR with Verma et al. at different drying temperatures

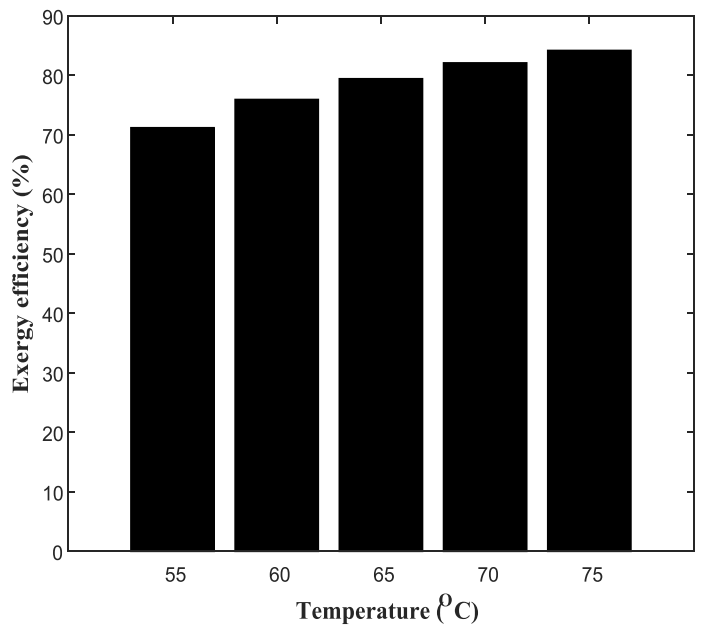

Figure 10 Exergy efficiency at different temperatures

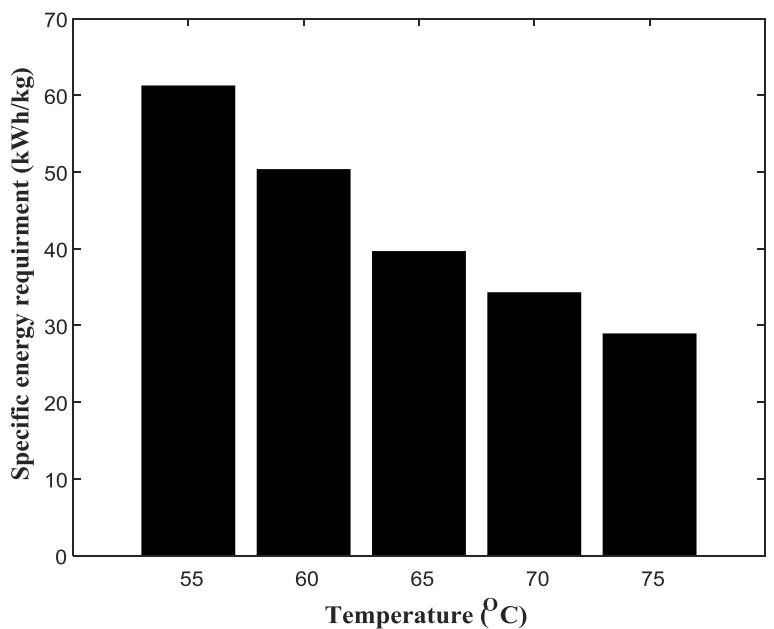

Figure 9 Specific energy requirement at different temperatures

energy consumption. The exergy efficiency of the tray dryer was increased with increase in drying air temperature during the drying of pineapple is presented in Figure 10. Similar findings were reported on the drying of green olive (Colak \& Hepbasli, 2007) and mint leaves (Colak et al., 2008).

\section{Conclusions}

The drying of pineapple occurred predominantly in the falling rate period and constant rate period was not observed in this work. It was observed that the increase in drying-air temperature increased in drying rate. The drying data in the form of moisture ratio was fitted to the different drying models. Among all selected models, Verma et al. (1985) was chosen as the best fit model to the experimental data to describe the thin-layer drying behaviour of pineapple. The increase in drying air temperature from 55 to $75^{\circ} \mathrm{C}$ was significantly affecting the specific energy requirement and exergy efficiency of the drying process.

Journal of Experimental Biology and Agriculture Science 


\section{References}

Abano EE, Ma H, Qu W (2011) Influence of air temperature on the drying kinetics and quality of tomato slices. Journal of Food Processing \& Technology 2:1-9. DOI: http://dx.doi.org/10.4172/2157-7110.1000123.

Aghbashlo M, Mohammad H, Kianmehr, Hadi Samimi-Akhijahani (2008) Influence of drying conditions on the effective moisture diffusivity energy of activation and energy consumption during the thin-layer drying of berberis fruit (Berberidaceae). Energy Conversion and Management 49:2865-2871. DOI: https://doi.org/10.1016/j.enconman.2008.03.009.

Akanbi CT, Adeyemi RS, Ojo A (2006) Drying characteristics and sorption isotherm of tomato slices. Journal of Food Engineering 73:157-163. DOI: https://doi.org/10.1016/j.jfoodeng.2005.01.015.

Akpinar EK (2006) Determination of suitable thin layer drying curve model for some vegetables and fruits. Journal of Food Engineering 73: 75-84. DOI: https://doi.org/10.1016/j.jfoodeng.2005.01.007.

Aviara NA, Onuoha LN, Falola OE, Igbeka JC (2014) Energy and exergy analyses of native cassava starch drying in a tray dryer. Energy 73:809-817. DOI: https://doi.org/10.1016/j.energy.2014.06.087.

Babalis SJ, Belessiotis VG (2004) Influence of the drying conditions on the drying constants and moisture diffusivity during the thin-layer drying of figs. Journal of Food Engineering 65:449458. DOI: https://doi.org/10.1016/j.jfoodeng.2004.02.005.

Bartolomé AP, Rupérez P, Fúster C (1995) Pineapple fruit: Morphological characteristics chemical composition and sensory analysis of red Spanish and smooth cayenne cultivars. Food Chemistry 53:75-79. DOI: https://doi.org/10.1016/03088146(95)95790-D.

Bon J, Simal S, Rossello C, Mulet A (1997) Drying characteristics of hemispherical solids. Journal of Food Engineering 34: 109-122. DOI: https://doi.org/10.1016/S0260-8774(97)00098-8.

Chakraverty A (1994) Post harvest technology of cereals pulses and oilseeds 3rd edition. Oxford and IBH Publishing Co Pvt Ltd New Delhi P 25.

Chen XD, Pirini W, Ozilgen M (2001) The reaction engineering approach to modelling of drying of thin layer of pulped Kiwifruit flesh under conditions of small Biot number. Chemical Engineering and Processing: Process Intensification 40: 311-320. DOI: https://doi.org/10.1016/S0255-2701(01)00108-8.

Colak N, Kuzgunkaya E, Hepbasli A (2008) Exergetic assessment of drying mint leaves in a heat pump dryer. Journal of Food Process Engineering 31:281-98. DOI: DOI: 10.1111/j.17454530.2007.00155.x.

Colak N, Hepbasli A (2007) Performance analysis of drying of green olive in a tray dryer. Journal of Food Engineering 80:11881193. DOI: https://doi.org/10.1016/j.jfoodeng.2006.09.017.
Corzo O, Bracho N, Vasquez A, Pereira A (2008) Energy and exergy analyses of thin layer drying of coroba slices. Journal of Food Engineering 86:151-61. DOI: https://doi.org/10.1016/j.jfoodeng.2007.05.008.

Crank J (1975) Mathematics of diffusions ( $2^{\text {nd }}$ ed) London: Oxford University Press.

Diamante L, Durand M, Savage G, Vanhanen L (2010) Effect of temperature on the drying characteristics colour and ascorbic acid content of green and gold kiwifruits. International Food Research Journal 17: 441-451.

Doymaz I (2007) The kinetics of forced convective air-drying of pumpkin slices. Journal of Food Engineering 79: 243-8. DOI: https://doi.org/10.1016/j.jfoodeng.2006.01.049.

Erbay Z, Icier F (2011) Energy and exergy analysis on drying of olive leaves (Olea europaca L) in tray drier. Journal of Food Process Engineering 34:2105-23. DOI: 10.1111/j.17454530.2009.00505.x

Goyal RK, Kingsly ARP, Manikantan MR, Ilyas SM (2006) Thinlayer drying kinetics of raw mango slices. Biosystem Engineering 95:43-49.

DOI: https://doi.org/10.1016/j.biosystemseng.2006.05.001.

Kaleemullah S, Kailappan, R (2005) Modelling of thin-layer drying kinetics of red chillies. Journal of Food Engineering 76:531-537. DOI: https://doi.org/10.1016/j.jfoodeng.2005.05.049.

Karathanos VT, Belessiotis, VG (1999) Application of a thin layer equation to drying data fresh and semi-dried fruits. Journal of Agricultural Engineering and Research 74: 355-361. DOI: https://doi.org/10.1006/jaer.1999.0473.

Kaya A, Aydin O, Kolayli S (2010) Effect of different drying conditions on the vitamin $\mathrm{C}$ (ascorbic acid) content of Hayward kiwifruits (Actinidia deliciosa Planch). Food and Bioproducts Processing 88:165-173. DOI: https://doi.org/10.1016/j.fbp.2008.12.001.

Kingsly RP, Goyal RK, Manikantan MR, Ilyas SM (2007) Effects of pre-treatment's and drying air temperature on drying behaviour of peach slice. International Journal of Food Science and Technology 42:65-69.

Koyuncu T, Pinar Y, Lule F (2007) Convective Drying Characteristics of Azarole Red (Crataegus monogyna Jacq) and Yellow (Crataegus aronia Bosc) Fruits. Journal of Food Engineering 78: 1471-1475. DOI: https://doi.org/10.1016/j.jfoodeng.2005.09.036.

Mirzaee E, Rafiee S, Keyhani A, Emam-Djomeh Z (2009) Determining of moisture diffusivity and activation energy in drying of apricots. Research in Agricultural Engineering 55 :114120 . 
Motevali A, Abbaszadeh A, Minaeil S, Khoshtaghaza MH, Ghobadian B (2012) Effective moisture diffusivity activation energy and energy consumption in thin-layer drying of Jujube (Zizyphus jujube Mill). Journal of Agricultural Science and Technology 14: 523-532.

Mujumdar AS (2014) Handbook of Industrial Drying Fourth Edition Transport properties in the drying of solids. Technology and Engineering CRC press Taylor and Francis group Pp 79.

Olanipekun BF, Tunde-Akintunde TY, Oyelade OJ, Adebisi MG, Adenaya TA (2015) Mathematical modelling of thin-layer Pineapple drying. Journal of Food Processing and Preservation 39:1431-1441. DOI: 10.1111/jfpp.12362.

Page GE (1949) Factors Influencing the Maximum Rates of Air Drying Shelled Corn in Thin Layers. MSc Thesis Purdue University, West Lafayette IN.

Pala M, Mahmutoglu T, Saygi B (1996) Effects of pre-treatment's on the quality of open-air and solar dried products. Food 40:137141. DOI: 10.1002/food.19960400308.

Reddy RS, Ravula PR, Arepally D, Munagala SR, Golla S (2017) Drying kinetics and modelling of mass transfer in thin layer convective drying of pineapple. Chemical Science International Journal 19 : 1-12. DOI : 10.9734/CSJI/2017/32746.

Roberts JS, Kidd DR, Padilla-Zakour O (2008) Drying kinetics of grape seeds. Journal of Food Engineering 89: 460-465. DOI: https://doi.org/10.1016/j.jfoodeng.2008.05.030.

Sacilik K, Elicin AK (2006) The thin layer drying characteristics of organic apple slices. Journal of Food Engineering 73:281-289.
DOI: https://doi.org/10.1016/j.jfoodeng.2005.03.024.

Sadasivam S, Manickam A (1992) Biochemical methods of agricultural sciences. Wiley Eastern Ltd, New Delhi pp189-191.

Santos PHS, Silva MA (2009) Kinetics of $L$-ascorbic acid degradation in pineapple drying under ethanolic atmosphere. Drying Technology: International Journal 27 : 947-954. DOI: http://dx.doi.org/10.1080/07373930902901950.

Srivastava VK, John J (2002) Deep bed grain drying modeling. Energy Conversion and Management 43 : 1689-1708. DOI: https://doi.org/10.1016/S0196-8904(01)00095-4.

Togrul IT, Pehlivan D (2003) Modelling of drying kinetics of single apricot. Journal of Food Engineering 58:23-32. DOI: https://doi.org/10.1016/S0260-8774(02)00329-1.

Verma LR, Bucklin RA, Endan JB, Wratten FT (1985) Effects of drying air parameters on rice drying models. Trans ASAE 28:296301. doi: 10.13031/2013.32245.

Wang Z, Sun J, Liao X, Chen F, Zhao G, Wu J, Hu X (2007) Mathematical modelling on hot air drying of thin layer apple pomace. Food Research International 40:39-46. DOI: https://doi.org/10.1016/j.foodres.2006.07.017.

Westerman PW, White GM, Ross IJ (1973) Relative humidity effect on the high temperature drying of shelled corn. Transaction of ASAE 16:1136-1139.

Yaldiz O, Ertekin C, Uzun HI (2001) Mathematical modelling of thin layer solar drying of Sultana grapes. Energy 26:457- 465. DOI: https://doi.org/10.1016/S0360-5442(01)00018-4. 